\title{
Geocenamus brevidens Associated with Reduced Yield of No-Till Annual Spring Wheat in Oregon
}

\author{
Richard W. Smiley, Professor, and Ruth G. Whittaker, Jennifer A. Gourlie, and Sandra A. Easley, Faculty Re- \\ search Assistants, Oregon State University, Columbia Basin Agricultural Research Center, P.O. Box 370, Pendleton \\ 97801
}

\begin{abstract}
Smiley, R. W., Whittaker, R. G., Gourlie, J. A., and Easley, S. A. 2006. Geocenamus brevidens associated with reduced yield of no-till annual spring wheat in Oregon. Plant Dis. 90:885-890.

Associations between stunt nematodes and yield of no-till annual spring wheat (Triticum aestivum) were examined at two eastern Oregon locations. Geocenamus brevidens was the only species detected at one location and was mixed with Tylenchorhynchus clarus at another location. Six cultivars were planted with or without application of aldicarb during 2001. Inverse correlations between yield and stunt nematode density were significant at the $G$. brevidens-only site $(P$ $=0.04)$ but not the $G$. brevidens $+T$. clarus site $(P=0.44)$. Yields were inversely correlated $(P<$ 0.01 ) with stunt nematode populations at both sites during 2002. Aldicarb improved grain yields at both locations during 2001 (17 and 24\%, $P<0.01$ ) but not at the single location treated with aldicarb during $2002(10 \%, P=0.06)$. A lack of association between yield and T. clarus in 19 previously unreported experiments is discussed. Reduced wheat yield in response to stunt nematodes in Oregon is likely due to parasitism by G. brevidens and not T. clarus. This is the first report associating G. brevidens with suppression of wheat yield in the Pacific Northwest. Further studies are needed to define cropping systems and locations where G. brevidens may cause economic damage.
\end{abstract}

Additional keywords: direct-drill, Heterodera avenae, Merlinius brevidens, Pratylenchus neglectus

Stunt nematodes are migratory plantparasitic nematodes cosmopolitan on roots of cereals, grasses, and many other plant species $(6,8,13,28,31)$. The taxonomy of this group of obligate ectoparasites is complex and in a state of transition $(1,4,5,9,29)$. Species in the genera Geocenamus, Merlinius, and Tylenchorhynchus are reported most frequently, and species in Nagelus, Paratrophurus, Quinisulcius, and other genera are reported infrequently. Identification of stunt nematode genera and species is difficult, as exemplified by more than 100 species differentiated in the genus Tylenchorhynchus (9). Although most stunt nematode species do not cause significant damage to plants, including the stunting symptom, all stunt nematodes feed on epidermal cells and root hairs mostly in the cell elongation region, and may cause roots to thicken and elongate at a reduced rate (19). Many species of stunt nematodes are multiplied efficiently into high populations without causing damage to wheat $(21,41)$ and other crops $(22)$.

Although stunt nematodes are not

Corresponding author: R. W. Smiley

E-mail: richard.smiley@oregonstate.edu

Accepted for publication 14 February 2006.

DOI: 10.1094/PD-90-0885

(C) 2006 The American Phytopathological Society among the species considered most important on cereals $(20,26)$, wheat (Triticum aestivum L.) has been significantly damaged by several species within this group. The species most recognized for the potential to damage wheat is Geocenamus brevidens (Allen, 1955) Brzeski, 1991 (16,19,27); synonyms include Merlinius brevidens [Allen, 1955] Siddiqi, 1970, and Tylenchorhynchus brevidens Allen, 1955. This species has been associated with roots of many grass, cereal, vegetable, legume, brassica, fruit, and fiber crops (30), and was first reported in the United States on wheat in Texas in 1959 (21). Other species that have reduced wheat plant growth and yield include $T$. brevilineatus (39), $T$. dubius $(12,28)$, and $T$. vulgaris $(23,24)$. Wheat plants parasitized by stunt nematodes may exhibit a chlorosis of lower leaves and reduction in plant height, tillering, head size, and kernel size (19).

Peak stunt nematode population densities may occur at varying soil depths depending on tillage systems and crop rotations. Populations of $T$. dubius were highest in the surface 25 to $28 \mathrm{~cm}$ of soil, and the vertical distribution within this profile was relatively stable throughout the year $(2,28)$. Detection of these ectotrophic species is most efficient by extracting juvenile and adult stages from soil. Eggs are released into soil as females feed on roots. A juvenile stage is released as the egg hatches, and each juvenile stage molts three times before reaching the adult stage. As many as three reproductive cycles may occur each crop year. While mating requirements differ among species, certain species such as G. brevidens and Tylenchorhynchus clarus Allen, 1955 are nearly always extracted from soil only as females that reproduce by parthenogenesis. Males of both species are either absent or rare.

Stunt nematodes of undetermined identity were detected in $78 \%$ of southeastern Idaho fields (38) and $35 \%$ of eastern Oregon and Washington fields (34) planted to cereals. In a more comprehensive survey of southern Idaho and eastern Oregon counties, Hafez et al. (8) detected $G$. brevidens in $15 \%$ of fields planted to wheat and in $38 \%$ of all fields planted to field, pasture, vegetable, and horticultural crops (8). One or more of nine Tylenchorhynchus spp. also were detected in $10 \%$ of wheat crops and $15 \%$ of all fields sampled (8). Most fields sampled in the Oregon and Washington survey (34) were planted annually to no-till spring cereals, a cropping system that favors development of high populations of stunt nematodes (40). The population density for stunt nematodes in Oregon and Washington was as high as $2,430 / \mathrm{kg}$ of soil in fields planted to no-till spring cereals (34). While this population clearly exceeded damage thresholds reported elsewhere $(16,19,24,28)$, the importance of stunt nematodes on field crops has not been investigated in the $\mathrm{Pa}$ cific Northwest.

This paper reports relationships between stunt nematodes and wheat yields in four field experiments at two Oregon farms where soils were infested by $G$. brevidens and at one farm, also with $T$. clarus.

\section{MATERIALS AND METHODS}

Field experiments were performed during 2001 and 2002 on annually cropped fields at two farms in Union County, OR. The fields were at $825-\mathrm{m}$ elevation in an area where annual precipitation averages $460 \mathrm{~mm}$ and mean air temperatures are $-1^{\circ} \mathrm{C}$ in January and $18^{\circ} \mathrm{C}$ in July and August.

Experimental procedures. Cuthbert Farm. The Cuthbert Farm, $10 \mathrm{~km}$ northeast of La Grande, has a deep, well-drained Imbler fine sandy loam; a coarse-loamy, mixed, superactive, mesic Pachic Haploxerolls. The experiment was performed on a field that had been planted to winter wheat 
during the autumn of 2000, after stubble of a perennial fine-leaf fescue crop was turned under with a moldboard plow. The field was fertilized (16-20-0, at $85 \mathrm{~kg}$ $\mathrm{N} / \mathrm{ha}$ ) and disked before winter wheat was planted on 18 October 2000. Winter wheat in the experimental area was killed by glyphosate herbicide on 21 March 2001. The experiment consisted of six spring wheat cultivars, Alpowa, Frame, Krichauff, Molineux, Penawawa, and Spear, planted with and without aldicarb (Temik 15G) and replicated four times in a two-way randomized complete block design. Wheat seed was treated with tebuconazole plus metalaxyl (Raxil XT) to suppress seed rot and seedling damping-off. The trial was planted into $1.5 \times 6.1 \mathrm{~m}$ plots on 16 April 2001 at 270 seeds $/ \mathrm{m}^{2}$ using a drill with a cone-seeder and four hoe-type openers at $36-\mathrm{cm}$ row spacing. Starter fertilizer (16$20-0$, at $11 \mathrm{~kg} \mathrm{~N} / \mathrm{ha}$ ) was applied by banding $2.5 \mathrm{~cm}$ below the seed at planting. Aldicarb was dispensed with the seed through the cone at $4.2 \mathrm{~kg}$ a.i./ha to reduce initial nematode populations (2). The field was irrigated with a center-pivot system, and weeds were controlled by hand weeding. After cutting 1-m alleys, yield was determined for $7.7 \mathrm{~m}^{2}$ plots by machine harvest at maturity during mid-August.

During 2002, a second experiment was performed in an adjacent field that had been fertilized and planted to winter wheat the previous autumn: October 2001. The experimental area was sprayed with glyphosate and uniformly planted into 36 plots of spring wheat cv. Zak on 19 April 2002 without additional tillage or application of fertilizer. Half of the plots were treated with aldicarb at planting. The field was not irrigated during 2002. Plots were sampled and harvested as described for experiments during 2001.

Wallender Farm. The Wallender Farm, $11 \mathrm{~km}$ east-southeast of La Grande, has a poorly drained Hooley silt loam; a medial over loamy, mixed over isolic, nonacid, mesic Typic Endoaquands. The experiment on a center-pivot irrigated field at the Wallender Farm during 2001 was similar to that at the Cuthbert Farm, except that the field at the Wallender Farm had been planted annually to no-till winter wheat. The same six cultivars were planted into an area where winter wheat was killed with glyphosate on 21 March 2001. There were four replications, with and without aldicarb, for a total of 48 plots planted as a two-way randomized complete block design on 16 April 2001. Starter fertilizer was banded below the seed, as previously described.

A second experiment was performed at the same site during 2002. Volunteer wheat in the plot area was sprayed with glyphosate on 2 April 2002. Without tillage, the 48 plots were planted uniformly to spring wheat cv. Zak on 19 April 2002. Starter fertilizer (16-20-0, at $22 \mathrm{~kg} \mathrm{~N} / \mathrm{ha}$ ) was applied by banding $2.5 \mathrm{~cm}$ below the seed at planting. Aldicarb was not applied during 2002. All plant and soil sampling, harvest measurements, and data analyses were performed to coincide with treatments applied to each specific plot during 2001.

Soil sampling and nematode extraction. Soil was collected before planting to assess plant-parasitic nematode populations in individual plots of all experiments. Soil was collected from marked plots usually within 2 days before being planted. Samples consisted of 15 to 20 cores (2.5 $\mathrm{cm}$ diameter $\times 20 \mathrm{~cm}$ deep) composited for each $10 \mathrm{~m}^{2}$ plot. Samples were placed on ice in the field and in a refrigerated room $\left(4^{\circ} \mathrm{C}\right)$ following collection and were stored for up to 14 days before being transported to the Oregon State University Nematode Testing Service at Corvallis.

Extractions of nematodes were performed using the standard "Whiteheadtray" method (10). Numbers of nematodes in each plant-parasitic genus or closely related genus complex were determined using standard morphological characteristics and measurements. Numbers are reported as nematodes per kilogram of ovendry soil. During 2001 and 2002, the stunt nematode population density in each plot was not differentiated into specific genera or species. During 2003, a detailed identification of stunt nematode genera and species for each experimental location was performed by the Oregon State University Nematode Testing Service. The species identification was conducted on a composite sample for each location, derived by aggregating subsamples from every plot sampled at that location during April 2002.

Statistical analysis. Nematode populations were described as the range, mean, and standard deviations among plots in whole experiments or within cultivar and nematicide variables. Nematode populations were normalized by transformation $(\ln +1)$ prior to being subjected to analysis of variance using Co-Stat Statistical Software version 6.303 (CoHort Software, Monterey, CA). Nematode populations and grain yields were analyzed using the twoway randomized complete block model during 2001. When cultivar or aldicarb treatment effects were significant at $P<$ 0.05 , means were separated using the least significant difference test (LSD). The 2002 experiment at the Wallender Farm was also analyzed using the two-way randomized complete block model, based on potential residual effects from cultivars and aldicarb treatments applied during 2001, and planting a single wheat cultivar uniformly without additional treatment variables during 2002. The one-way randomized complete block model was used to analyze the nematicide variable at the Cuthbert Farm during 2002. During both years, associations between initial populations of nematodes and grain yields were evaluated by regression analysis using a linear model for individual plots in whole experiments or within experimental variables. In selected instances, stepwise backward multiple regression analysis was utilized to determine if the association between yield and nematode population was strengthened by including multiple species of plantparasitic nematodes in the analysis.

\section{RESULTS}

Cuthbert Farm. G. brevidens was the only stunt nematode species detected at the Cuthbert Farm. During 2001, the 48 plots had preplant populations ranging from 0 to $240 / \mathrm{kg}$ of soil; mean $=28$ and standard deviation $=56$. Populations did not differ for cultivar $(P=0.84)$ or nematicide treatment $(P=0.43)$. Grain yields averaged $4,003 \mathrm{~kg} / \mathrm{ha}$ and did not differ among cultivars $(P=0.09)$ and were improved $17 \%$ by aldicarb treatment; 4,323 versus 3,682 $\mathrm{kg} / \mathrm{ha}, P=0.0025, \mathrm{LSD}_{0.05}=258$. There was no significant interaction $(P=0.16)$ among cultivar and aldicarb treatments.

When wheat yield was regressed against initial nematode populations in all 48 plots, yield was weakly inversely correlated with $G$. brevidens $\left(P=0.0350, r^{2}=\right.$ $0.09)$ and Pratylenchus neglectus ( $P=$ $0.0533, r^{2}=0.08$ ) but not Heterodera avenae $(P=0.42)$. When aldicarb-treated plots were analyzed separately, yield was not associated with populations of $G$. brevidens $(P=0.97), H$. avenae $(P=0.27)$, or $P$. neglectus $(P=0.40)$. In control plots, wheat yield for the combined cultivars was more strongly inversely correlated with $G$. brevidens $\left(P=0.0003, r^{2}=0.53\right)$ (Fig. 1) than with $P$. neglectus $\left(P=0.0467, r^{2}=\right.$ 0.18 ) and was not associated with $H$. avenae $(P=0.90)$. The initial analysis showed the presence of two outliers in data presented in Figure 1. When outliers for $G$. brevidens populations exceeding 100/kg of soil were removed, the regression coefficient $\left(r^{2}\right)$ was more modest; yield $=4,015$ $-12.2 x ; r^{2}=0.21, P=0.0315, n=22$. When yields were regressed against multiple variables, the regression coefficient for G. brevidens alone (Fig. 1) was not improved by addition of other variables, such as $P$. neglectus.

For individual cultivars in control plots, significant negative correlations occurred between $G$. brevidens and yields of Alpowa $\left(P=0.0103, r^{2}=0.98\right)$ and Krichauff $\left(P=0.0292, r^{2}=0.94\right)$. These two varieties had initial $G$. brevidens mean populations of 35 and $60 / \mathrm{kg}$ of soil, with maximum densities of 140 and $240 / \mathrm{kg}$, respectively. Yields of the other four cultivars were not correlated significantly with G. brevidens, and each was planted into plots with lower initial G. brevidens populations, with means $<30 / \mathrm{kg}$ of soil and maximum populations $<60 / \mathrm{kg}$ in individual plots.

During 2002, the G. brevidens population in 36 plots ranged from 0 to $380 / \mathrm{kg}$ of 
soil; mean $=75$, standard deviation $=101$. Grain yield for this nonirrigated planting of spring wheat cv. Zak averaged 1,093 $\mathrm{kg} / \mathrm{ha}$ and did not differ $(P=0.06)$ in aldicarb and control treatments; 1,146 and $1,040 \mathrm{~kg} / \mathrm{ha}$, respectively. Yield for all treatments was inversely correlated $(P<$ $\left.0.0001, r^{2}=0.55\right)$ with $G$. brevidens. Regression slopes for yield and $G$. brevidens populations differed $(P=0.0315)$ in aldicarb and control treatments (Fig. 2), indicating a greater impact of increasing $G$. brevidens population density in aldicarbtreated than in untreated soil. Yield was not correlated with $P$. neglectus in control $(P=$ $0.57)$, aldicarb $(P=0.18)$, or combined $(P$ $=0.35)$ treatments.

Wallender Farm. Stunt nematodes occurred as a mixture of $30 \%$ G. brevidens and $70 \%$ T. clarus. During 2001, the combined population ranged from 0 to $970 / \mathrm{kg}$ of soil; mean $=170$, standard deviation $=$ 245. Preplant populations differed significantly in plots subsequently divided into cultivar $(P=0.0249)$ but not aldicarb $(P=$ $0.38)$ treatments. Mean populations were highest $\left(\mathrm{LSD}_{0.05}=194\right)$ for plots planted to Krichauff (359) and Penawawa (236), intermediate for Molineux (188) and Spear (143), and lowest for Frame (78) and Alpowa (34).

Grain yields averaged $2,576 \mathrm{~kg} / \mathrm{ha}$ and differed significantly among cultivar $(P=$ $0.0405)$ and aldicarb $(P<0.0001)$ treatments. Plots treated with aldicarb yielded $24 \%$ more grain than the controls; 2,848 versus $2,304 \mathrm{~kg} / \mathrm{ha}, \mathrm{LSD}_{0.05}=173$. Average yields for Alpowa, Frame, Krichauff, Molineux, Penawawa, and Spear were $2,480,2,362,2,764,2,530,2,793$, and $2,525 \mathrm{~kg} / \mathrm{ha}$, respectively; $\mathrm{LSD}_{0.05}=244$.

Yield for the combined cultivars was not correlated with $G$. brevidens plus $T$. clarus for the control $(P=0.44)$, aldicarb $(P=$ $0.15)$, or combined $(P=0.46)$ treatments. Grain yield for Alpowa was significantly inversely correlated $(P=0.0006)$ with $G$. brevidens plus $T$. clarus (Fig. 3) when aldicarb and control treatments were grouped. Correlations were not significant for other cultivars, all of which had nematode population means and maxima higher than for Alpowa. Populations of P. neglectus were not significantly correlated with yields for any cultivar, and a very low population of $H$. avenae was detected in only one of 48 plots.

When individual cultivars were evaluated for aldicarb-treated plots, yields were not significantly correlated with the initial population of stunt nematodes; " $P$ " values ranged from 0.18 to 0.96 . When individual cultivars were evaluated for control plots, stunt nematodes were significantly inversely correlated with yield for Alpowa $(P=0.0466)$, Frame $(P=0.0143)$, and Spear $(P=0.0432)$, each of which had initial mean populations less than 100 nematodes $/ \mathrm{kg}$ of soil; means and ranges were 40 (0-100), $88(0-250)$, and 95 (0-

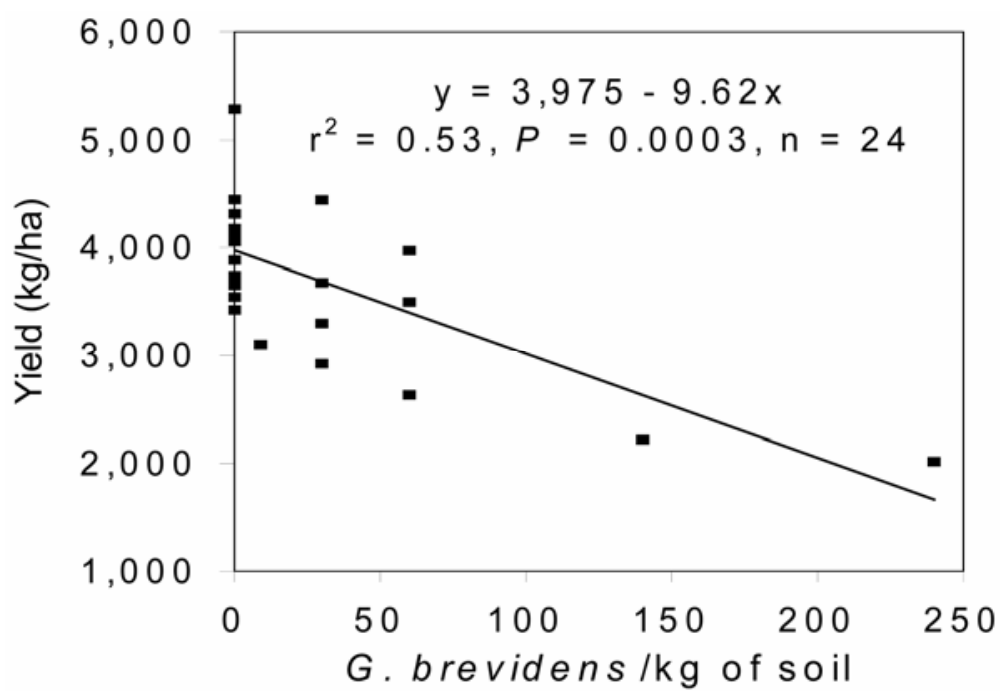

Fig. 1. Relationship between grain yield for six spring wheat cultivars and preplant population of Geocenamus brevidens in control plots (not treated with aldicarb) at the Cuthbert Farm during 2001.

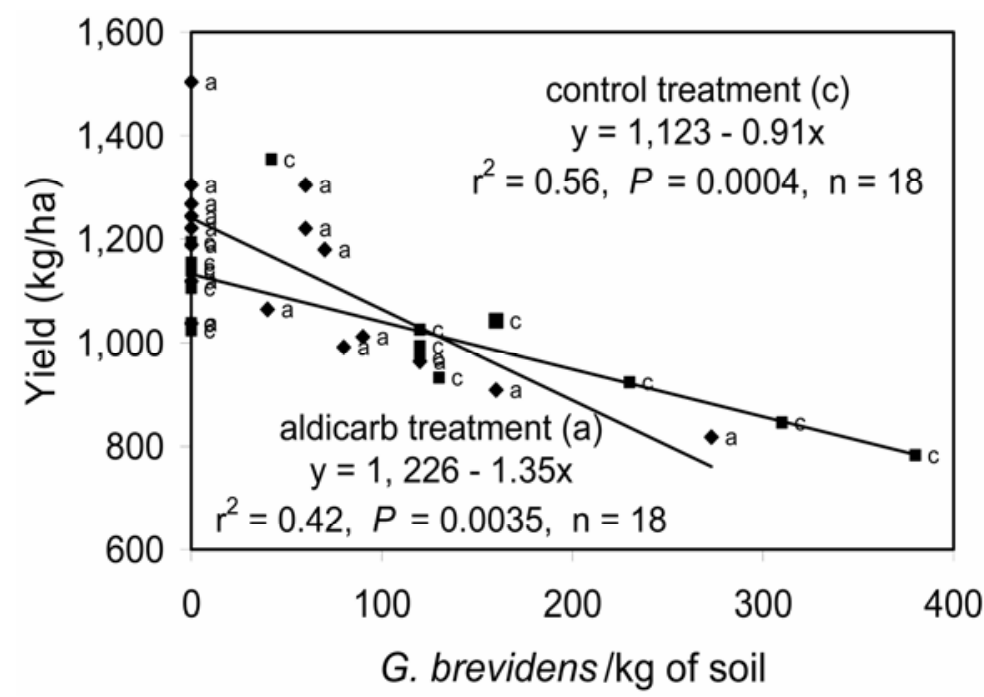

Fig. 2. Relationship between grain yield for spring wheat cv. Zak and preplant population of Geocenamus brevidens at the Cuthbert Farm during 2002; data are from aldicarb (a) and control (c) treatments, with slopes of regression lines differing at $P=0.0315$.

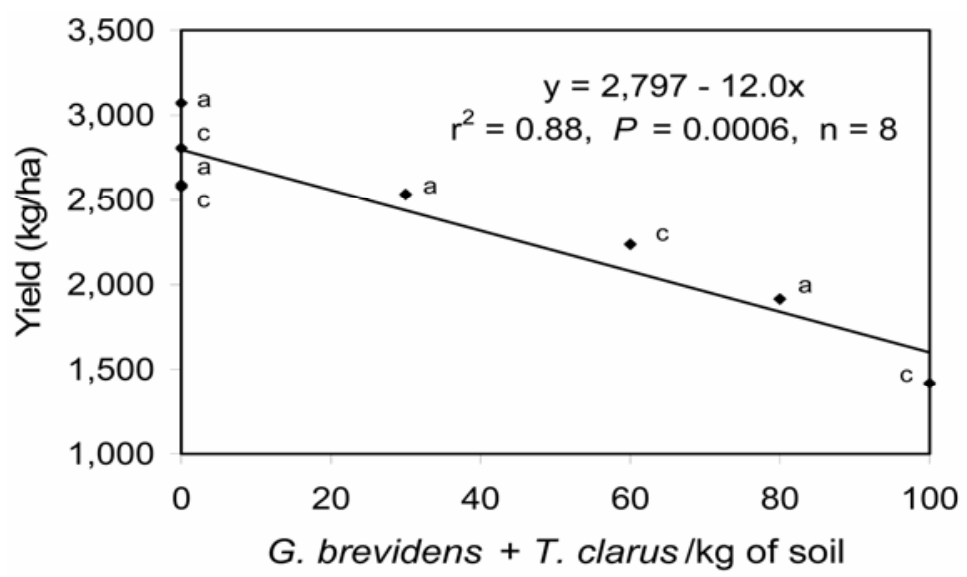

Fig. 3. Relationship between grain yield for spring wheat cv. Alpowa and preplant population of Geocenamus brevidens (30\%) plus Tylenchorhynchus clarus $(70 \%)$ in plots subsequently treated with aldicarb (a) or left untreated (c) while planting at the Wallender Farm during 2001. 
380), respectively. Stunt nematodes in the control plots were not significantly correlated with yield for Krichauff $(P=0.58)$, Molineux $(P=0.50)$, and Penawawa $(P=$ $0.57)$, each of which had mean initial populations exceeding 100 nematodes $/ \mathrm{kg}$ of soil and minimum numbers exceeding 60 nematodes $/ \mathrm{kg}$ of soil; means and ranges were 527 (150-970), 110 (60-160), and 323 (160-400), respectively. When yields for each cultivar were regressed against populations of multiple nematode species, there was no relationship more significant than the association with the $G$. brevidens and $T$. clarus mixture.

During 2002, the mixed population ranged from 0 to $980 / \mathrm{kg}$ of soil, with a mean of $162 / \mathrm{kg}$ and standard deviation of 243. Following the treatments applied during 2001, there were no significant differences among nematode populations in plots treated with aldicarb $(P=0.19)$ or for cultivar variable $(P=0.42)$. Likewise, these variables did not have significant effects on the apparent reproductive ratio $\mathrm{Pf} / \mathrm{Pi}$, where Pf was the preplant population during 2002 and $\mathrm{Pi}$ was the preplant population in the same plots during 2001; $P=0.20$ for cultivar treatments and $P=$ 0.25 for aldicarb treatments. The $\mathrm{Pf} / \mathrm{Pi}$ ratio was highest for plots that had the lowest initial populations during 2001, with the inverse correlation between $\mathrm{Pf} / \mathrm{Pi}$ ratio and initial population significant at $P$ $=0.0503$.

Yield of Zak in this irrigated planting was very low $(439 \mathrm{~kg} / \mathrm{ha})$ due to combined effects from two late-season frosts, one of which occurred immediately after an herbicide application that resulted in a pronounced phytotoxic response. Yield was inversely correlated with populations of $G$. brevidens plus $T$. clarus $(P=0.0012)$ (Fig. $4)$ but not $P$. neglectus $(P=0.48)$.

\section{DISCUSSION}

Yield of spring wheat was inversely correlated with populations of stunt nematodes at two locations during each of 2 years. G. brevidens was present at both locations and was mixed with $T$. clarus at one location. No association between spring wheat yield and stunt nematode population was detected in 19 experiments of similar design at four locations where $T$. clarus was the only species of stunt nematode detected (unreported data). We conclude that $G$. brevidens but not $T$. clarus is responsible for suppressing yield of annual no-till spring wheat in eastern Oregon.

Four additional experiments, reported elsewhere $(36,37)$, were also performed at the two $G$. brevidens-infested locations reported in this paper. Associations between stunt nematodes and yields were not detectable in the previously reported experiments, presumably because damage in those experiments was associated with the more aggressive plant-parasitic species $P$. neglectus (36) and $H$. avenae (37). Suppression of wheat yield by $G$. brevidens appeared to be detectable only when damage could not be associated with the more aggressive species.

Wheat yield was statistically $(P<0.05)$ greater (17 and 24\%) following application of aldicarb in two of three experiments where the nematicide was applied while planting the current crop. Yield improvement $(10 \%)$ in the third such experiment was significant at $P=0.06$. At the single location where wheat was planted into the same experimental block during two consecutive years, and planted without application of additional variables during the second year, there was no detectable residual influence of aldicarb on the initial population of stunt nematodes prior to planting the second crop, one year following aldicarb application. Previous studies with aldicarb application have shown a near-tripling of yield at initial populations of 9,840 T. vulgaris $/ \mathrm{kg}$ of soil (24).

Detection of plant damage by stunt nematodes is difficult. At high levels of parasitism, plants may become chlorotic and stunted, may produce fewer tillers and heads, and may tend to be aggregated into distinct patches $(16,19)$. We did not observe definitive symptoms in the plant

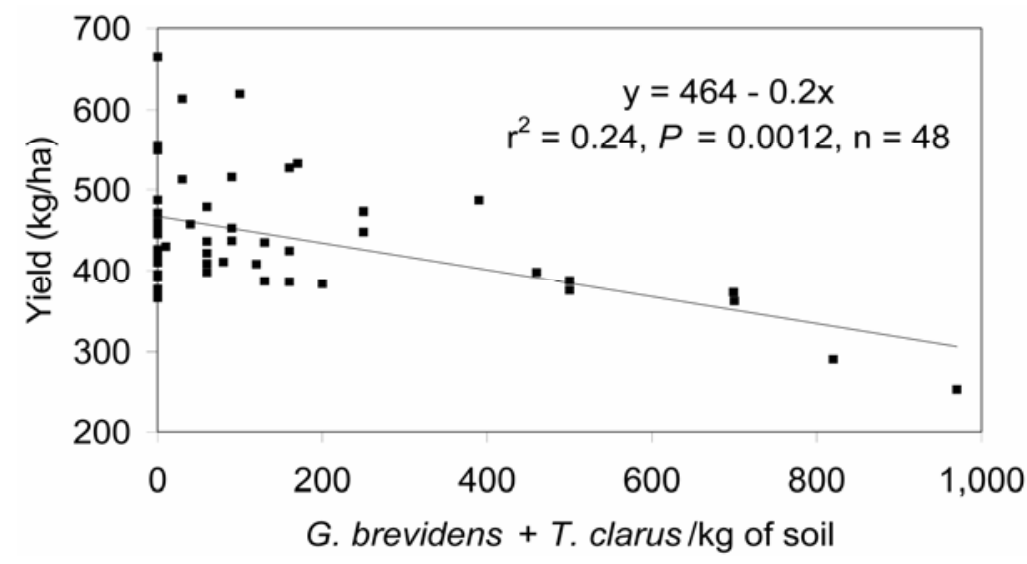

Fig. 4. Relationship between grain yield for spring wheat cv. Zak and preplant population of Geocenamus brevidens (30\%) plus Tylenchorhynchus clarus (70\%) at the Wallender Farm during 2002. canopy during experiments reported here. Plants parasitized by $G$. brevidens are also characterized as having fewer and shorter roots but no distinct lesions or premature necrosis of root tissue $(16,19)$. Roots in our experiments were excavated to evaluate symptoms of diseases caused by soilborne root-infecting fungi (25). During the course of those evaluations (unreported data), there were no distinct abnormalities noted on roots that could be definitively attributed to damage by $G$. brevidens, but we did not attempt to quantify possible differences in root diameters or lengths.

Studies of stunt nematodes on wheat have shown a large divergence in apparent damage threshold, presumably depending on differences in local characteristics of soil, plants or plant cultivars, experimental conditions, and possibly also the aggressiveness of different populations. In controlled-environment experiments, a population density of approximately $1,200 \mathrm{G}$. brevidens $/ \mathrm{kg}$ of soil reduced weights of wheat roots and shoots by $40 \%$ (19). In a similar experiment, a population of about 660 G. brevidens $/ \mathrm{kg}$ did not cause stunting, whereas populations greater than $2,000 / \mathrm{kg}$ were associated with severe plant stunting and reduced wheat yield (16). In field studies, populations exceeding 2,000 G. brevidens $/ \mathrm{kg}$ were associated with plant stunting and reduced grain yield (13). Wheat growth was reduced by 40 and $24 \%$ in the presence of $T$. dubius at $67 / \mathrm{kg}$ of soil (28) and 5,000/kg of soil (12), respectively. The damage threshold for $T$. vulgaris on wheat occurred between 200 and $1,500 / \mathrm{kg}$ of soil (24).

In our studies, inverse associations between wheat yield and population densities of $G$. brevidens appeared to occur at very low initial population densities. During 2001, a G. brevidens population exceeding 30 to $50 / \mathrm{kg}$ of soil was associated with yield suppression in the sandy loam at the Cuthbert Farm. Populations higher than 100 to $200 / \mathrm{kg}$ appeared necessary to suppress yields at the same location during 2002. In the silt loam at the Wallender Farm, correlations between yield and populations of the G. brevidens $+T$. clarus mixture occurred only when the initial population was between 0 and $60 / \mathrm{kg}$ and did not occur when the initial population was higher than $60 / \mathrm{kg}$. Although reasons for this observation are unclear, it appears that in this soil, under the restricted crop growth conditions experienced during 2001, initial mean populations of stunt nematodes higher than $100 / \mathrm{kg}$ may have induced a uniform suppression of wheat growth in a manner suggestive of a saturation response. It is also possible that this observation may have been an anomaly resulting from the spatial heterogeneity which led to significant differences in preplant populations in plots planted to individual cultivars at the Wallender Farm during 2001. This appears likely because 
yield of a single cultivar at the same site during 2002 was negatively correlated with increasing populations of the $G$. brevidens plus $T$. clarus mixture over the full range of initial population densities. Additional research in the Pacific Northwest is required to examine this possibility and particularly to establish more precise estimates of thresholds for economic damage.

Patel and Thakar (24) suggested that wheat cultivars differed in tolerance to parasitism by $T$. vulgaris. In our experiments with six cultivars during 2001, the cultivar Alpowa was significantly negatively correlated with stunt nematode populations in control plots (without aldicarb treatment) at both locations. Additionally, the cultivar Krichauff was also negatively correlated with $G$. brevidens population at the Cuthbert Farm but not with the mixed population of G. brevidens and T. clarus at the Wallender Farm. In contrast, in addition to Alpowa, cultivars negatively associated with $G$. brevidens plus T. clarus at the Wallender Farm but not the Cuthbert Farm included Frame and Spear. Differences in response of the six cultivars at each location appeared to relate more to heterogeneity in initial density of stunt nematodes in individual plots than to genetic traits for the cultivars examined in these experiments. Nevertheless, these experiments were not adequately replicated over locations and years to identify possible differences in cultivar responses to damage by $G$. brevidens.

Langdon et al. (16) reported that damage caused by $G$. brevidens alone was less severe than when soils were infested with both G. brevidens and Olpidium brassicae, an obligate parasitic protista (fungus-like organism). Boag et al. (3) also concluded that yield reductions were more likely from combined populations of Pratylenchus, Tylenchorhynchus, and other genera than from individual genera of plantparasitic nematodes. When we regressed yield against multiple measures of root damage attributable to various soilborne plant-pathogenic fungi (unreported) and populations of all extractable plantparasitic nematode genera, we found no association that was more important than for stunt nematodes alone.

Distribution of $G$. brevidens in the Pacific Northwest has not been reported. Identifications of stunt nematode species were not performed during surveys of plant-parasitic nematodes in Idaho (38) and in Oregon and Washington (34). Stunt nematode species identified in a survey of Idaho and eastern Oregon (8) were reported by crop association but not geographic location. In our experiments in eastern Oregon, G. brevidens was detected in an area characterized by fewer growingdegree days and lower January temperatures than for four locations where T. clarus but not $G$. brevidens was detected. These temperature characteristics are ma- jor determinants for distinguishing geoclimatic zones in the western United States (11). The region where G. brevidens was detected has a 30-year mean average 820 growing-degree days $\left(0^{\circ} \mathrm{C}\right.$ base $)$ from 1 January to 1 May (calculated from http://pnwpest.org/wea/, Integrated Plant Protection Center, Oregon State University, Corvallis), which is comparable to the range of values (417 to 964) occurring in locations where $G$. brevidens was detected by Hafez et al. (8). We detected only $T$. clarus at four locations characterized by an average of 1,100 to 1,250 growing-degree days from 1 January to 1 May. Minimum and maximum mean daily January temperatures are several degrees lower in the area where we detected G. brevidens compared to $T$. clarus (calculated from http://www.ocs.oregonstate.edu/prism/; 7). These distinctions are of interest because maximum multiplication rates for $G$. brevidens (18) occur at lower temperatures (10 to $20^{\circ} \mathrm{C}$ ) than for $T$. clarus (20 to $35^{\circ} \mathrm{C}$ ). By applying these growing-degreeday and temperature calculators to areas where $G$. brevidens has been detected in this and previous studies, it is clear that this species causes economic damage in regions characterized by colder $(6,14)$, equally cold $(16,17,27)$, and warmer $(15,19,21,31,40)$ winters than those where G. brevidens was or was not detected in Oregon. Additionally, distribution maps for these species in California (31) indicate that the occurrence of $G$. brevidens extends into colder regions than $T$. clarus in California, and that each species is distributed throughout warmer regions of that state. It therefore appears that temperature relationships detected in our study are unlikely to be a major single determinate of the distribution of $G$. brevidens in Oregon or elsewhere in the Pacific Northwest. More likely, the distribution pattern we observed was an artifact relating to site-selection criteria designed to examine damage relationships for $H$. avenae (37), P. neglectus (36), and P. thornei (35).

Crop management practices that minimize damage from $G$. brevidens have not been studied in the Pacific Northwest. Crops that favor efficient multiplication of this species include wheat, barley, oats, and field pea (17). Poor hosts include alfalfa, potato, and sugar beet (17). Populations of $G$. brevidens decline rapidly in the absence of a host (19), indicating that populations may be expected to be higher in annual crops than in 2-year rotations of winter wheat with summer fallow. Also, populations become higher and potentially more damaging in no-till than in cultivated fields (40). Management of G. brevidens population density is particularly important during the seedling growth stage (19). Aldicarb and other nematicides are not registered for this use on wheat in the United States.

Soil samples for this investigation were collected to a depth of $20 \mathrm{~cm}$, consistent with shallow depths (15 to $25 \mathrm{~cm}$ ) reported previously $(12,14,21,28)$ but not as deep (50 to $150 \mathrm{~cm}$ ) as for some studies $(2,8,40)$. Stunt nematodes are vertically distributed to considerable depth in soil, but their population is generally greatest in the upper $25 \mathrm{~cm}(2,12,28)$. Sampling protocols in our experiments were considered adequate for characterizing relative differences in nematode species and populations in large numbers of plots.

This paper presents the first evidence that $G$. brevidens is associated with suppression of wheat yield in the Pacific Northwest. This report supplements previous evidence that wheat is damaged by $H$. avenae (33,37), P. thornei (35) and P. neglectus (36), and a complex of fungi (Fusarium, Pythium, Rhizoctonia, and Gaeumannomyces spp.) in the Pacific Northwest $(25,32)$. Additional research is needed to more fully describe the importance of $G$. brevidens in the complex of root- and crown-infecting fungi and plantparasitic nematodes affecting wheat in the northwestern United States.

\section{ACKNOWLEDGMENTS}

We thank wheat producers John Cuthbert and Fred and Tim Wallender for hosting field experiments, and Kathy Merrifield, Nadine Wade, Nick David, and Russell Ingham (Oregon State University Nematode Testing Service, Corvallis) for nematode quantification and identification services. We thank Abby Burnett and Nichole Kellogg for technical assistance. This research was funded by an OSU subcontract to the USDA-Agricultural Research Service: SCA\#58-5348-9-100, "Control of Root Diseases of Wheat and Barley".

\section{LITERATURE CITED}

1. Anderson, R. V., and Potter, J. W. 1991. Stunt nematodes: Tylenchorhynchus, Merlinius, and related genera. Pages 529-586 in: Manual of Agricultural Nematology. W. R. Nickle, ed. Marcel Dekker, New York.

2. Beane, J. 1985. Vertical distribution of Pratylenchus neglectus, P. crenatus and Tylenchorhynchus dubius associated with maize roots and the effect of aldicarb residues. Ann. Appl. Biol. 106:499-503.

3. Boag, B., Bowen, S., Spaull, A. M., Wright, G., and Smith, B. F. L. 1990. Migratory plantparasitic nematodes associated with cereals in Scotland. Ann. Appl. Biol. 117:399-406.

4. Brzeski, M. 1991. Taxonomy of Geocenamus Thorne \& Malek, 1968 (Nematoda: Belonolaimidae). Nematologica 37:125-173.

5. Brzeski, M. W., and Dolinski, C. M. 1998. Compendium of the genus Tylenchorhynchus Cobb, 1913 sensu lato (Nematoda: Belonolaimidae). Russian J. Nematol. 6:189-199.

6. Celetti, M. J., Johnson, H. W., Kimpinski, J., Platt, H. W., and Martin, R. A. 1990. Incidence of soil-borne plant pathogens isolated from barley and winter wheat, and other crops in the rotation, on Prince Edward Island. Plant Pathol. 39:606-611.

7. Daley, C., Gibson, W. P., Taylor, G. H., Johnson, G. L., and Pasteris, P. 2002. A knowledgebased approach to the statistical mapping of climate. Clim. Res. 22:99-113.

8. Hafez, S. I., Golden, A. M., Rashid, F., and Handoo, Z. 1992. Plant-parasitic nematodes associated with crops in Idaho and eastern Oregon. Nematropica 22:193-204.

9. Handoo, Z. A. 2000. A key and diagnostic compendium to the species of the genus Tylenchorhynchus Cobb, 1913 (Nematoda: Be- 
lonolaimidae). J. Nematol. 32:20-34.

10. Ingham, R. E. 1994. Nematodes. Pages 459490 in: Methods of Soil Analysis, Part 2. R. W. Weaver, ed. Microbiological and Biochemical Properties. American Society of Agronomy, Madison, WI.

11. Jallala, A. M., and Araji, A. A. 1982. Geoclimatic zones in the western region. Univ. Idaho Agric. Exp. Stn. Res. Bull. 126. Moscow, ID.

12. Jones, R. K. 1979. Migratory plant parasitic nematodes as pests of cereals. Ann. Appl. Biol. 92:257-262.

13. Jordaan, E. M., van den Berg, E., and de Waele, D. 1992. Plant-parasitic nematodes on field crops in South Africa. 5. Wheat. Fund. Appl. Nematol. 15:531-537.

14. Kimpinski, J., Anderson, R. V., Johnston, H. W., and Martin, R. A. 1989. Nematodes and fungal diseases in barley and wheat on Prince Edward Island. Crop Prot. 8:412-416.

15. Kleyhans, K. P. N., van den Berg, E., Swart, A., Marais, M., and Buckley, N. H. 1996. Plant Nematodes in South Africa. Plant Prot. Res. Inst. Handb. No. 8, Pretoria, South Africa.

16. Langdon, K. R., Struble, F. B., and Young, H. C., Jr. 1961. Stunt of small grains, a new disease caused by the nematode Tylenchorhynchus brevidens. Plant Dis. Rep. 45:248-352.

17. Luth, P. 1990. Study of the factors influencing the development of populations of the ectotrophic root nematode Merlinius brevidens (Allen, 1955) Siddiqi, 1970. Nachrich. Pflanzen. DDR 44:212-214.

18. Malek, R. B. 1980. Population response to temperature in the subfamily Tylenchorhynchinae. J. Nematol. 12:1-6.

19. Mayol, P. S. 1981. Pathogenicity of Merlinius brevidens as related to host development. Plant Dis. 65:248-250.

20. Nicol, J. M. 2002. Important nematode pests of cereals. Pages 345-366 in: Bread Wheat: Improvement and Production. B. C. Curtis, ed. FAO Plant Production and Protection Series, Rome, Italy.
21. Norton, D. C. 1959. Relationships of nematodes to small grains and native grasses in North and Central Texas. Plant Dis. Rep. 43:227-235.

22. Oostenbrink, M., S'Jacob, J. J., and Kuiper, K. 1956. An interpretation of some crop rotation experiences based on nematode surveys and population studies. Nematologica 1:202-215.

23. Patel, A. S., and Patel, H. R. 1990. Host range of stunt nematode, Tylenchorhynchus vulgaris. Indian J. Mycol. Plant Pathol. 20:176-178.

24. Patel, P. N., and Thakar, N. A. 1989. Damaging threshold level of the stunt nematode, Tylenchorhynchus vulgaris on wheat variety, J-24. Indian J. Nematol. 19:78.

25. Paulitz, T., Smiley, R., and Cook, R. J. 2002. Insights into the prevalence and management of soilborne cereal pathogens under direct seeding in the Pacific Northwest U.S.A. Can. J. Plant Pathol. 24:416-428.

26. Rivoal, R., and Cook, R. 1993. Nematode pests of cereals. Pages 259-303 in: Plant Parasitic Nematodes in Temperate Agriculture. K. Evans, D. L. Trudgill, and J. M. Webster, eds. CAB International, Wallingford, UK.

27. Schlehuber, A. M., Pass, J., and Young, H. C., Jr. 1965. Wheat grain losses caused by nematodes. Plant Dis. Rep. 49:806-809.

28. Sharma, R. D. 1971. Studies of the plant parasitic nematode Tylenchorhynchus dubius. Meded. LandbHogesch. Wageningen 71-1.

29. Siddiqi, M. R. 1970. On the plant-parasitic nematode genera Merlinius gen. n. and Tylenchorhynchus Cobb and the classification of the families Dolichodoridae and Belonolaimidae n. rank. Proc. Helminth. Soc. Wash. 37:68-77.

30. Siddiqi, M. R. 1972. Merlinius brevidens. Descriptions of Plant-Parasitic Nematodes, Set 1, No. 8. Commonwealth Institute of Helminthology, St. Albans, Herts., England.

31. Siddiqui, I. A., Sher, S. A., and French, A. M. 1973. Distribution of Plant Parasitic Nematodes in California. Dep. Food Agric., Sacramento, CA

32. Smiley, R. W. 1996. Diseases of wheat and barley in conservation cropping systems of the semiarid Pacific Northwest. Am. J. Altern. Agric. 11:95-103.

33. Smiley, R. W., Ingham, R. E., Uddin, W., and Cook, G. H. 1994. Crop sequences for managing cereal cyst nematode and fungal pathogens of winter wheat. Plant Dis. 78:1142-1149.

34. Smiley, R. W., Merrifield, K., Patterson, L.-M., Whittaker, R. G., Gourlie, J. A., and Easley, S. A. 2004. Nematodes in dryland field crops in the semiarid Pacific Northwest USA. J. Nematol. 36:54-68

35. Smiley, R. W., Whittaker, R. G., Gourlie, J. A., and Easley, S. A. 2005. Pratylenchus thorne associated with reduced wheat yield in Oregon. J. Nematol. 37:45-54.

36. Smiley, R. W., Whittaker, R. G., Gourlie, J. A., and Easley, S. A. 2005. Suppression of wheat growth and yield by Pratylenchus neglectus in the Pacific Northwest. Plant Dis. 89:958-968.

37. Smiley, R. W., Whittaker, R. G., Gourlie, J. A., Easley, S. A., and Ingham, R. E. 2005. Plantparasitic nematodes associated with reduced wheat yield in Oregon: Heterodera avenae. J. Nematol. 37:297-307.

38. Strausbaugh, C. A., Bradley, C. A., Koehn, A. C., and Forster, R. L. 2004. Survey of root diseases of wheat and barley in southeastern Idaho. Can. J. Plant Pathol. 26:167-176.

39. Thakar, N. A., Patel, H. R., and Patel, C. C. 1986. Damaging threshold level of the stunt nematode, Tylenchorhynchus brevilineatus on wheat variety, Sonalika. Ind. J. Nematol. 16:260-261

40. Thompson, J. P. 1992. Soil biotic and biochemical factors in a long-term tillage and stubble management experiment on a vertisol. 2. Nitrogen deficiency with zero tillage and stubble retention. Soil Tillage Res. 22:339361.

41. Vendietti, M. E., and Noel, G. R. 1995. Comparative host suitability of selected crop species to Tylenchorhynchus zambiensis. Nematropica 25:15-25. 